\title{
Perlawanan Ideologi Moderatisme Melawan Hegemoni Radikalisme Dalam Novel Tuhan, Izinkan Aku Menjadi Pelacur! Karya Muhidin M. Dahlan (Tinjauan Sosiologi Sastra: Hegemoni Gramsci)
}

\author{
Rr. Via Rahmawati \\ Fakultas Ilmu Budaya Universitas Diponegoro \\ Viacimbuk@gmail.com
}

\begin{abstract}
This research entitled "The Resistance of the Ideology of Moderatism Against Hegemony Radicalism In God's Novel, Allow Me to Become a Slut! The work of Muhidin M. Dahlan (Review of Sociology of Letters: Hegemoni Gramsci) ", focuses attention on the existence of two ideological oppositions in God's novel, Allow Me to Become a Whore! the work of Muhidin M. Dahlan. God's novel, Allow Me to Become a Whore! recounts religious organizations Jamaah Daulah Islamiyah who want to rule over the government of Indonesia and want to realize his ideals to establish Daulah Islamiyah Indonesia. The results of this study indicate that the ideology of moderateism that Kiran fought against the hegemony of radicalism Jamaah Daulah Islamiyah organization, although he must make strong resistance and protest against the organization.

Keywords: Hegemony, Ideology, Daulah Islamiyah.
\end{abstract}

\section{Intisari}

Penelitian ini berjudul "Perlawanan Ideologi Moderatisme Melawan Hegemoni Radikalisme dalam Novel Tuhan, Izinkan Aku Menjadi Pelacur! Karya Muhidin M. Dahlan (Tinjauan Sosiologi Sastra: Hegemoni Gramsci)", memfokuskan perhatian pada adanya dua perlawanan ideologi yang ada dalam novel Tuhan, Izinkan Aku Menjadi Pelacur! karya Muhidin M. Dahlan. Novel Tuhan, Izinkan Aku Menjadi Pelacur! menceritakan organisasi keagamaan Jamaah Daulah Islamiyah yang ingin berkuasa atas pemerintahan Indonesia dan ingin mewujudkan cita-citanya mendirikan Daulah Islamiyah Indonesia. Penelitian ini bertujuan untuk menjawab tiga permasalahan, yaitu 1) menjelaskan unsur struktur khusus tema, tokoh, plot, latar yang membangun novel Tuhan, Izinkan Aku Menjadi Pelacur!; 2) mengungkapkan ideologi apa sajakah yang muncul dalam novel Tuhan, Izinkan Aku Menjadi Pelacur!; 3) mengungkapkan perlawanan ideologi moderatisme yang diperjuangkan Kiran dalam melawan hegemoni radikalisme Jamaah Daulah Islamiyah. Metode yang digunakan adalah deskriptif kualitatif dengan memahami isi serta menggambarkan gejala keadaan yang terjadi dalam novel. Hasil penelitian menunjukkan bahwa adanya dua bentuk perlawanan ideologi, yaitu ideologi moderatisme dan ideologi radikalisme. Ideologi moderatisme adalah ideologi yang digunakan untuk melawan ketidaksesuaian ajaran yang diajarkan oleh Jamaah Daulah Islamiyah dan ideologi radikalisme adalah ideologi yang digunakan untuk melawan pemerintah.

Kata kunci: Hegemoni, Ideologi, Daulah Islamiyah. 


\section{PENDAHULUAN}

Novel Tuhan, Izinkan Aku Menjadi Pelacur! (tahun 2010) karya Muhidin M. Dahlan menceritakan pemahaman agama Islam garis keras yang mencita-citakan tegaknya Daulah Islam di Indonesia. Tokoh utama novel ini, Nidah Kirani, seorang mahasiswa yang sedang mencari jati diri, terperosok ke dalam lubang hitam sebuah organisasi keagamaan. Organisasi yang diyakini dapat mengubah keadaan masyarakat menjadi lebih baik dengan cara-cara yang telah diajarkan dalam syariat justru mengantarkannya pada satu titik terendah.

Darul Islam atau DI yang artinya adalah "Negara Islam" yang bercita-cita mendirikan Daulah Islam di Indonesia, mereka menjanjikan kemakmuran dan kesejahteraan bagi mereka yang meyakini. Suatu tujuan yang mulia, namun cita-cita yang tampak indah itu tidak berjalan selaras dalam praktiknya.

Tokoh yang dipresentasikan Muhidin M. Dahlan dalam menggambarkan situasi demikian adalah Nidah Kirani. Nidah Kirani merupakan seorang mahasiswa yang ingin meningkatkan ilmu dan pemahamannya tentang agama. Ia bergabung ke dalam organisasi Daulah Islamiyah yang bercita-cita menegakkan syariat Islam Indonesia dan mendirikan Daulah Islamiyah Indonesia. Padahal organisasi yang ia yakini tersebut merupakan suatu organisasi radikal.

Berdasarkan uraian di atas, pertanyaan mendasar yang akan dikemukakan dalam tesis ini adalah 1) bagaimanakah unsur struktur khusus tema, tokoh, plot, latar yang membangun aspek sosial masyarakat dalam novel Tuhan, Izinkan Aku Menjadi Pelacur! karya Muhidin M. Dahlan; 2) ideologi-ideologi apa sajakah yang muncul dalam novel Tuhan, Izinkan Aku Menjadi Pelacur! karya Muhidin M. Dahlan; 3) Bagaimanakah perlawanan ideologi moderatisme yang diperjuangkan Kiran mampu melawan hegemoni radikalisme Jamaah Daulah Islamiyah yang bercita-cita mendirikan Daulah Islamiyah di Indonesia.

Suatu karya sastra tidak cukup dipahami jika hanya diteliti strukturnya saja tanpa kerjasama dengan disiplin ilmu lain. Hal ini karena masalah yang terkandung di dalam suatu karya sastra pada dasarnya merupakan masalah masyarakat. Sosiologi sastra merupakan kajian tentang segala sesuatu menyangkut masyarakat, termasuk permasalahannya dan kaitannya dengan hajat hidup orang banyak.

Sapardi Djoko Damono, mengatakan bahwa pendekatan terhadap karya sastra yang mempertimbangkan segi-segi kemasyarakatan disebut sosiologi sastra. Karya sastra 
merupakan gambaran kenyataan kehidupan masyarakat dan peristiwa yang mengungkapkan segi-segi sosial karena masalah yang dilukiskan dalam karya sastra merupakan masalah yang ada di lingkungan kehidupan pengarangnya (1984:1). Escarpit (2005:14) sosiologi sastra harus memperlihatkan kekhasan fakta sastra. Dengan memberikan keuntungan kepada para profesional (home de metier), ia harus juga menguntungkan pembaca dengan jalan membantu ilmu sastra tradisional-sejarah atau kritik dalam tugas-tugas khusus yang harus menjadi cakupannya. Secara tidak langsung kegiatan itu tetap menjadi tugasnya: peranannya adalah mengamatinya pada tingkatan masyarakat. Hegemoni dalam bahasa Yunani kuno disebut eugemonia sebagaimana dikemukakan Ensyclopedia Britanica dalam praktiknya di Yunani, diterapkan untuk menunjukkan dominasi posisi yang diklaim oleh negara-negara kota (polis atau city states) secara individual, misalnya yang dilakukan oleh negara kota Athena dan Sparta, terhadap negara-negara lain yang sejajar (Hendarto, 1973:73). Hegemoni merupakan sebuah rantai kemenangan yang didapat melalui mekanisme konsesus ketimbang melalui penindasan terhadap kelas sosial lainnya. Gramsci dengan menggunakan konsensus atau persetujuan. Konsep ini digunakan sebagai suatu gerakan penguasa secara perang posisi bukan perang gerakan. Istilah perang posisi diartikan sebagai suatu proses transformasi kultural untuk "menghancurkan sebuah hegemoni dan menggantikannya dengan hegemoni lain" (Gramsci, 1971:57).

\section{METODE PENELITIAN}

Metode, sesuai pernyataan Hasan dan Koentjaraningrat (1997:16), berarti cara kerja untuk memahami suatu objek yang dikaji. Suatu metode dipilih dengan mempertimbangkan kesesuaian dengan objek studi, yaitu novel Tuhan, Izinkan Aku Menjadi Pelacur!. Novel ini akan dikaji ke dalam dua tahap, yaitu pertama dari segi struktur yang membangun terwujudnya novel, dan kedua pada bagaimana memahami isi dengan menggunakakan pendekatan sosiologi sastra hegemoni gramsci. 


\section{HASIL PENELITIAN}

\section{Ideologi Radikalisme}

\section{Menganggap Pemerintah Indonesia Sebagai Pemerintah Thaghut}

Dalam novel TIAMP thaghut diartikan sebagai pemerintahan kafir yang tidak berkesesuaian dengan hukum Islam dan belum berjalan berdasarkan syariat Islam. Jadi, meskipun seseorang telah melakukan ibadah sebaik mungkin akan percuma dan tidak diterima oleh Allah karena negara mereka belum menggunakan syariat Islam sebagai dasar hidupnya. Berikut adalah kutipannya.

"Dokumen itu sangat rahasia. Tidak boleh jatuh ke tangan pemerintah kafir Indonesia. Kita bisa hancur kalau itu terjadi," kata Mbak Auliah dengan paras serius sungguh (TIAMP:58).

\section{Memiliki Ikatan Emosional yang Kuat dengan Kelompok daripada Ikatan Emosional}

\section{Keluarga}

Berkurangnya empati kepada keluarga dan lebih memilih mementingkan kepentingan kelompoknya merupakan salah satu indikasi terkena paham radikal. Selain itu ciri selanjutnya adalah menjadi pribadi yang tertutup dan enggan bersosialisasi dengan orang lain di luar komunitasnya. Berikut adalah salah satu kutipan yang menggambarkan rasa empati Kiran berkurang dengan keluarga setelah ia bergabung dengan kelompok Jamaah Daulah Islamiyah.

...Dan kurasai pula infak yang kuberikan juga sudah cukup banyak. Aku harus mengeluarkan uang paling minim 500 ribu setiap minggunya untuk kas perjuangan. Dan uang itu kuperoleh dari kantong kakakku di luar negeri dan kedua orang tuaku dengan alasan untuk membayar uang kuliah, uang semester, uang buku, dan sebagainya (TIAMP:60).

Dari kutipan tersebut diketahui jika Kiran berani membohongi orang tua dan kakaknya. Ia lebih memilih menggunakan uang yang diberikan untuknya untuk disetorkan sebagai uang infaq. Ia lebih memilih jamaahnya daripada keluarganya.

\section{Kaderisasi Dilakukan Secara Tertutup}

Dalam proses pengkaderisasian calon jamaahnya pun begitu mereka lakukan dengan tertutup. Calon jamaah harus bersedia melewati berbagai macam tes seleksi sebelum 
Rr. Via Rahmawati, Perlawanan Ideologi Moderatisme Melawan Hegemoni Radikalisme Dalam Novel Tuhan, Izinkan Aku Menjadi Pelacur! Karya Muhidin M. Dahlan

dinyatakan lulus menjadi anggota jamaah. Mereka melakukan proses perekrutan ini secara tertutup, sembunyi-sembunyi top secret.

...Sepenuturan Mas Dahiri lagi, aku dinyatakan lulus screening, sebuah uji dan teror kejiwaan. Tahulah aku bahwa gerakan ini tak sembarang merekrut kadernya. Mereka tak ingin orang yang masuk setengah-setengah. Jadi, hanya orang yang sudah dicabut akarnya yang bisa diterima. Dan aku adalah salah seorang yang telah dicabuti akar keberagamaannya di mana ajaran yang kupahami selama ini tidak benar dan harus dibersihkan. Dan setelah semuanya tercerabut, sedikit demi sedikit ditanami bibit akidah yang baru (TIAMP: 45).

\section{Membayar Uang Infaq Sebagai Uang Perjuangan}

Setiap minggunya Kiran dan jamaah yang lain diwajibkan memberikan uang infaq dengan jumlah yang cukup besar sebagai uang perjuangan. Dan organisasi Jamaah Daulah Islamiyah memperbolehkan jamaahnya memperoleh uang dari mana saja.

...Dan kurasai pula infak yang kuberikan juga sudah cukup banyak. Aku harus mengeluarkan uang paling minim 500 ribu setiap minggunya untuk kas perjuangan. Dan uang itu kuperoleh dari kantong kakakku di luar negeri dan kedua orang tuaku dengan alasan untuk membayar uang kuliah, uang semester, uang buku, dan sebagainya (TIAMP:60).

Bagi organisasi ini sumber pendanaan bisa diperoleh dari mana saja karena mereka berkeyakinan jika semua kekayaan bangsa Indonesia sudah dirampas oleh pemerintah kafir, sehingga diperbolehkan dengan berbagai cara untuk mendapatkannya, termasuk berbohong, merampok, dan mencuri karena mereka sedang berjihad dan Allah mengetahui niat baik mereka, sebab pendanaan tersebut bukan untuk foya-foya.

"Kita boleh berbohong, sepanjang itu berkaitan dengan kepentingan Islam dan kerahasiaan perjuangan. Bahkan, boleh menipu, mencuri, merampok, menjual barang-barang pribadi, maupun melacur. Ini jihad dan bukan untuk foya-foya. Dan Allah Maha Tahu itu semua," begitu aku ingat seorang ustad di Jemaahku sesaat setelah aku dilantik. Walau aku sangat begidik waktu itu, toh kuterima dengan pasrah. Sebab anggapanku ini perjuangan mulia (TIAMP:60-61).

\section{Bercelana Cingkrang dan Berjenggot Bagi Lelaki, Berjilbab Besar ataupun Bercadar}

\section{Bagi Perempuan}

Keberadaan wanita bercadar maupun perkumpulan wanita bercadar pada umumnya mendapat reaksi yang beragam dari masyarakat yang tidak sedikit di antaranya merupakan stigma negatif. Hal tersebut kemudian juga berpengaruh terhadap penerimaan masyarakat terhadap wanita bercadar yang diidentifikasikan sebagai kaum minoritas karena memiliki 
Rr. Via Rahmawati, Perlawanan Ideologi Moderatisme Melawan Hegemoni Radikalisme Dalam Novel Tuhan, Izinkan Aku Menjadi Pelacur! Karya Muhidin M. Dahlan

penampilan yang berbeda dan mencolok dibandingkan dengan wanita muslim pada umumnya.

Sikap masyarakat yang terbagi menjadi pro dan kontra dalam menyikapi keberadaan wanita bercadar pada dasarnya juga tidak dapat dipisahkan dari adanya pendapat yang bertentangan dari para ulama mengenai apakah penggunaan cadar bagi wanita Muslim adalah suatu keharusan atau tidak. Apabila ditinjau dari sudut pandang sosial, adanya perspektif negatif dalam memandang wanita bercadar tidak dapat dipungkiri. Penggunaan cadar yang dilakukan oleh para muslimah tersebut dianggap mengganggu proses hubungan antar pribadi dalam bermasyarakat. Al Asymawi (dalam Shihab) menganggap penggunaan cadar sebagai hambatan untuk menciptakan keadaan yang lebih baik, di mana hubungan positif di antara masyarakat menjadi semakin sulit karena melihat wajah adalah sesuatu yang fundamental dalam hubungan antar sesama (Shihab, 2006:22).

Kiran pun mengalami tindakan yang kurang menyenangkan dari dari lingkungan sekitar. Ada sebuah perasaan yang tidak mengenakkan yang dilontarkan beberapa temannya. Berikut kutipannya.

Tapi atas segala kehambaan itu aku pun digunjingi hanya karena jilbab dan jubahku besar. Bahkan ada yang bilang: "Tuh liat, tekstil jalan." Tapi aku menunduk saja, menunduk, dan menunduk, sebagaimana Rasul pernah mengajarkan. Salahkah aku berpakaian demikian? Bukankah aku hanya menuruti perintah Allah dalam Al-Quran surah An-Nuur ayat 31 yang memerintahkan agar menutup aurat serapat-rapatnya. Salahkah aku berpakaian yang demikian dan mengurangi aktivitas keduniawian? (TIAMP:43).

\section{Umat Islam di Luar Kelompoknya Dianggap Kafir Sebelum Mereka Berhijrah}

Ciri dari kelompok radikal selanjutnya adalah menganggap orang Islam di luar kelompoknya kafir. Dan dalam novel TIAMP jelas sekali menekankan hal tersebut. Tidak jarang, Jamaah Daulah Islamiyah membawa dalil-dalil Al-Quran untuk meyakinkan jamaah jika pemahaman mereka tentang Islam selama ini salah, dan yang benar hanya Islam berdasarkan Daulah Islamiyah, sehingga orang yang belum berhijrah dan di luar kelompok mereka adalah kafir.

Dengan tercerabutnya akar beragama yang memang kuakui sangat lemah itu, maka betapa mudahnya aku menerima dengan total semua doktrin gerakan di mana aku harus mengakui bahwa selama ini aku bukan Islam. Dalil yang menjelaskan itu adalah surat Al-Maidah Qs. Al-Maidah (5):44, yakni kalau kamu belum berpegang pada hukum Islam kamu adalah zalim, kafir. Dan aku amat sadar bahwa posisiku sekarang ini tak lain adalah: KAFIR. Aku menyambut seutuh-utuhnya ajaran dan 
Rr. Via Rahmawati, Perlawanan Ideologi Moderatisme Melawan Hegemoni Radikalisme Dalam Novel Tuhan, Izinkan Aku Menjadi Pelacur! Karya Muhidin M. Dahlan

keyakinan baruku itu karena ajakan itu bersamaan dengan lempangnya hatiku untuk masuk Islam secara kaffah. TIAMP:46).

\section{Ideologi Moderatisme Islam}

\section{Tawassut (Moderat)}

Dalam novel Tuhan, Izinkan Aku Menjadi Pelacur! karya Muhidin M. Dahlan, sikap moderat tergambar dari sikap Kiran yang cenderung memilih jalan tengah untuk menghindari perselisihan yang terjadi antara dirinya dengan komandan Sardi. Ketika ia sadar telah mengajukan pertanyaan sensitif mengenai pergerakan intern jamaah, ia sadar jika pertanyaannya tersebut bisa memicu perselisihan antara dirinya dengan komandan Sardi, sehingga Kiran membelokkan pertanyaannya tersebut ke hal lain, sehingga perselisihan tidak terjadi.

...Sepenuturan Mbak Auliah, Komandan Sardi adalah salah satu ikhwan yang dituakan dalam jemaah kami ini. Dari dia aku mencoba menanyakan soal politik lembaga, tapi dia hanya menyambar hal-hal yang bersifat umum: tentang adanya ancaman Amerika dan sekutu-sekutunya atas Indonesia belakangan. Dia sama sekali tidak mau menjelaskan strategi politik Jemaah dan apa sasaran ke depan yang global, tapi umat di bawah seperti aku ini, sebagaimana yang aku tangkap, kayanya tak perlu tahu masalah real yang dihadapi Jemaah, selain ditugasi dan terus ditugasi untuk menggaet anggota baru sebanyak-banyaknya.

Mungkin Komandan Sardi enggan menjawab setiap tanyaku karena pertanyaan itu nyerempetke soal politik yang itu kalau tidak dijawab secara hati-hati akan menggoyahkan keselamatan gerakan Jemaah. Apalagi aku adalah kader termuda yang masih seumur jagung.

Sadar akan hal itu, aku mengalihkan pertanyaan ke hal lain. Ke soal sufi. Aku merindukan kehidupan sepi para pemburu spiritual ini yang di Pos ini kurasakan begitu hambar. Kutanyakan kepadanya apa pandangannya tentang sufi. (TIAMP:63$65)$.

Sikap Kiran tersebut digolongkan ke dalam moderat. Di mana ia lebih memilih menghindarkan konflik daripada harus meneruskan pertanyaannya, sehingga terjadi sesuatu yang tidak diinginkan. Ia memilih jalan tengah untuk meminimalisir benturan dan kekacauan yang bisa terjadi.

Selain itu sikap moderat lainnya ditunjukkan ketika Kiran berdiskusi dengan Rahmi. Dari percakapan itu diketahui jika Rahmi merupakan seorang wanita yang salehah, dan mau diajak bertukar pikiran. Dari sana terlihat jika karakter Rahmi termasuk dalam moderat 
karena selalu memberikan solusi-solusi terbaik. Oleh karena itu, kebaikan-kebaikan Rahmi menular kepada Kiran.

Dan Rahmi adalah orang yang ranjangnya berdekatan dengan ranjangku yang kemudian kutahu bahwa aku memiliki kecocokan dengannya: dia mau diajak bertukar pandang tentang agama, tentang suasana hati yang galau, tentang apa saja yang menyangkut soal-soal hati yang sedang meracau. Dia adalah orang yang mau mendengar dan aku selalu saja bercerita tentang semua masalahku dengannya.

Ketekunannya beribadah pun tertular kepadaku. Aku pun mulai bisa salat tepat waktu dan berjamaah di masjid yang tepat berada di depan asrama putri (TIAMP:28-29).

\section{Tawazun (Berimbang)}

Dalam novel Tuhan, Izinkan Aku Menjadi Pelacur! karya Muhidin M. Dahlan sikap tawazun digambarkan dari perilaku para anggota jamaah yang lebih bersemangat dengan acara kumpul bersama dengan anggota yang lain daripada melakukan dakwah. Mereka lebih banyak bersantai, sehingga tidak ada keseimbangan yang para anggota jamaah cerminkan.

Sudah sebulan aku menjadi warga baru di Pos. Dan aku merasakan ada suasana lain, suasana aneh yang sama sekali di luar dugaanku. Pandangan awalku, tentu sosok-sosok aktivis Jemaah ini adalah mereka seperti yang selalu dikatakan oleh Nabi: Pada siang harinya mereka seperti singa-singa padang pasir, dan malamnya seperti rahib yang bermunajat kepada Tuhannya. Tapi kok, kenapa anggapanku itu berbenturan dengan kenyataan yang ada di Pos Jemaah. (TIAMP:59).

Mereka tidak mencerminkan sebagaimana orang yang sedang berjihad menegakkan akidah umat Islam Indonesia yang salah. Meskipun, ada beberapa jamaah yang melakukan dakwah, namun hanya sedikit jumlahnya. Kiran kecewa, ia tidak pernah berpikir jika jamaah yang ia agung-agungkan akan mengecewakannya segini rupa. Semua yang telah Kiran korbankan seakan dikhianati oleh jamaah. Niat suci, perjuangan, dan pengorbanannya seakan percuma.

\section{Tasamuh (Toleransi)}

Dalam novel TIAMP yang menggambarkan adanya tasamuh adalah saat Kiran menjalankan ibadah puasa dan seorang teman membelikannya ayam bakar sebagai lauk untuk di makan saat berbuka puasa.

Suatu hari seorang santri pria yang juga mahasiswa Kampus Jaket Biru membelikanku ayam bakar untuk berbuka karena dia tahu bahwa aku puasa tiap hari. Dan ia pun tahu bahwa aku hanya makan roti tawar. Karena ia tahu hidupku seperti 
Rr. Via Rahmawati, Perlawanan Ideologi Moderatisme Melawan Hegemoni Radikalisme Dalam Novel Tuhan, Izinkan Aku Menjadi Pelacur!

Karya Muhidin M. Dahlan

itu, ia pun mengutus seorang temannya untuk membelikanku ayam bakar (TIAMP:52).

Dalam kutipan di atas digambarkan bagaimana indahnya ketika seseorang bisa bersikap tasamuh. Ia bisa belajar bertenggang rasa, menghargai, dan menghormati sesama. Bukan hanya sesama muslim, namun juga terhadap non muslim. Sikap tasamuh juga berarti sikap toleran yang tidak mementingkan diri sendiri dan juga tidak memaksakan kehendak.

\section{I'tidal (Bersikap Adil)}

Dalam novel TIAMP sikap i'tidal tergambar lewat kepemimpinan komandan Sardi yang tidak mencerminkan keadilan. Kekuasaan dan sikap otoriter yang melekat pada komandan Sardi mengakibatkan relasi antarkelas dalam konteks sosial masyarakat jamaah menjadi persoalan dan menimbulkan gejolak. Kiran dan ketiga temannya merasa terjadi ketidakadilan dalam kelompok Jamaah Daulah Islamiyah. Mereka yang merupakan anggota jamaah tidak diperbolehkan mengikuti Kongres Mujahidin yang sedang digelar.

"Kita ini bodoh juga ya, kenapa Kongres Mujahidin saja kita tidak bisa ikuti. Bodoh ya, mungkin ada sesuatu yang mereka sembunyikan. Coba kenapa. Padahal itu cuma kongres dan itu juga bagian dari perjuangan umat Islam. Tapi kita dilarang" (TIAMP:91).

"Saya juga heran tuh. Sama sekali kita tidak tahu bagaimana jaringan kita. Saya pikir adalah suatu kemustahilan bisa bergerak sendiri. Cita-cita sebesar yang diusung Jemaah ini tidak mungkin bisa diwujudkan tanpa gerakan yang lain. Tapi kita? Uh, pusing-pusing-pusing...," sahut Winda sambil tangan kanannya memulumukuli dahinya ?? (TIAMP:91).

\section{Ideologi Endapan: Kultural}

Dalam penelitian ini akan meminjam teori hegemoni kultural Antonio Gramsci untuk melihat kinerja hegemonik sebuah kepemimpinan. Cara melihat kinerja teori hegemoni dilakukan dengan melihat mekanisme kerja elemen-elemen yang mendasari terbentuknya teori. Beberapa elemen yang mendasari terbentuknya teori antara lain konsensus, intelektual, dan krisis hegemonik.

\section{Konsensus: Pelegalan sebuah Sistem Subordinasi}

Persoalan subordinasi kelas penguasa terhadap kelas yang dikuasai merupakan cikal bakal terjadinya pertarungan kelas, baik perang posisi (war of position) maupun perang gerakan 
(war of movement). Akan tetapi, proses subordinasi tidak akan menimbulkan polemik bila dalam proses subordinasinya diletakkan atas dasar konsensus. Artinya, kelas penguasa menerapkan subordinasi tanpa paksaan, sedangkan kelas yang dikuasai menerima subordinasi secara sukarela dan harus turut dijaga. Ada beberapa bukti penerimaan atas subordinasi yang ada dalam novel Tuhan, Izinkan Aku Menjadi Pelacur! adalah ketika Kiran bingung atas ketidakjelasan program-program pergerakan yang tidak pernah dipublikasikan kepada para jamaah. Mereka merasa seperti hanya ditugasi dan diperintah untuk berdakwah, tetapi tidak diberi penjalasan bagaimana program terperinci mengenai pergerakan itu.

Tiap minggu yang dia kasih cuma ceramah yang itu-itu saja yang itu sangat membosankan, "Dakwah ya. Kalian itu disuruh berdakwah. Berdakwalah." Ketika kutanya apa sasarannya ke depan, jawaban yang ia berikan berputar di situ lagi (TIAMP:85).

"Ah, mungkin ketiadaan penjelasan itu karena inilah jalan yang terbaik yang ditempuh oleh Jemaah. Mungkin maksudnya menutupi ketika aku sudah bertanya begini-begitu, tapi kok tidak dijelaskan, adalah demi keslamatan Jemaah. Misalkan saja aku ditangkap lalu disiksa dan bisa jadi aku tak sanggup untuk tak membongkar jaringan. Mungkin karena itu alasannya sehingga akses jaringan diputus-putus agar rahasia Jemaah terselamatkan"/(TIAMP:87).

\section{Intelektual (Kaum Intelektual dan Hiprokritas Ustad)}

Peran intelektual sebagai organiser hegemoni begitu penting dan dominan. Kaum intelektual merupakan deputi dari kelompok dominan yang menjalankan fungsi khusus dari hegemoni sosial dan pemerintahan sosial. Menurut Gramsci ada dua tipe intelektual, di antaranya adalah intelektual organik. Selain intelektual organik, ada intelektual tradisional. Tiap-tiap intelektual mempunyai peran dan fungsi masing-masing. Intelektual organik merupakan kelompok yang berhubungan dengan cara produksi yang dominan. Intelektual ini memberikan kelas homogenitas dan kesadaran akan fungsinya sendiri bukan hanya pada ekonomi, namun juga lapangan sosial dan politik. Intelektual ini bisa berasal dari kelas borjuis dan memihak mereka, bisa juga dari kelas proletar dan memihak kelompoknya. Kelompok intelektual organik ini berpotensi ke massa. Kebutuhan kontak antar kaum intelektual dan bersahaja bukan untuk membatasi aktivitas ilmiah dan mempertahankan kesatuan pada tingkat massa yang rendah, tetapi justru untuk membangun suatu blok intelektual moral yang memungkinkan kemajuan intelektual massa, bukan saja intelektual kecil (Bellamy: 1990:199, Patria dan Arief, 2003:162). Dan memberikan sebuah pandangan 
Rr. Via Rahmawati, Perlawanan Ideologi Moderatisme Melawan Hegemoni Radikalisme Dalam Novel Tuhan, Izinkan Aku Menjadi Pelacur! Karya Muhidin M. Dahlan

dunia baru serta menciptakan kesatuan antara bagian bawah dan atas (Patria dan Arief, 2003:161-162).

Dalam novel TIAMP yang merepresentasikan intelektual organik dalam konteks ini adalah Dahiri. Novel TIAMP menampilkan sistem kerja sama antara kaum intelektual dengan penguasa. Dahiri menggunakan simbol agama dalam perekrutan calon jamaah. Ia memasukkan doktrin mengenai keagamaan Kiran yang keliru. Dahiri meyakinkan jika semua pemahaman yang Kiran pahami selama ini masih jauh dari ajaran Islam yang sesungguhnya.

"Kuulangi sekali lagi padamu bahwa keislaman kita di Indonesia belum ada apa-apanya, belum murni. Kita masih pada fase Mekkah. Islam yang sah adalah Islam fase Madinah. Dan sekarang Islam Madinah itu belum juga ada dan masih dalam taraf di-usahakan. Islam Madinah adalah Islam Negara. Daulah. Keabsahan beragama dan tegaknya syariat tadi ditentukan oleh apakah kita memiliki daulah atau tidak. Dan kami punya rencana besar untuk mengusahakan berdirinya Daulah Islamiyah Indonesia" (TIAMP:39).

\section{Krisis Hegemoni (Perang Posisi Kiran: terhadap Komandan Sardi)}

Dalam novel TIAMP perang posisi perlawanan terjadi pada tokoh Kiran sebagai representasi kelas subordinat terhadap komandan Sardi sebagai repesentasi kelas dominan. Perlawanan Nidah Kirani terjadi sebagai akibat dari kegagalan komandan Sardi menjaga dan menjalankan hegemoni melalui aparatusnya, bahkan komandan Sardi berbuat semena-menan terhadap jamaah, sehingga memicu aktivitas revolusioner (Patria dan Arief, 2003:169). Kesemena-menangan tersebut memicu rakyat (jamaah) bergerak dan melawan. Melalui konflik sosial yang disebabkan oleh kesemena-menangan komandan Sardi terhadap Kiran, Winda, Meli, Lilis, maka kelas subordinat melakukan gerakan revolusi (perlawanan). Hal ini sejalan dengan yang digagas Gramsci bahwa revolusi tindakan harus didahului dengan revolusi mental.

Dan ternyata bukan aku saja yang merasakan kekecewaan itu. Benih yang sama juga tertanam dalam hati tiga kawanku di Pos Gamping. Posisiku sebagai wakil waliummah (pengurus rumah), seakan tidak berarti dalam Pos. Menurut kabar yang kudengar dari kawan karibku yang sepenanggungan, ketika aku diasingkan dulu, mereka hampir pecah. Ketika balik lagi, mereka membocorkan semua yang mereka tidak setujui dalam Pos, terutama kepala waliummahnya, Ukhti Hastinah, yang sangat galak itu (TIAMP:88-89).

"Iya, kenapa kita tidak boleh tahu soal itu. Kalau memang ini adalah perjuangan, kenapa mesti ditutup-tutupi?" sambung Lilis, si centil pemilik kamar $($ TIAMP:90). 
Ketidakterbukaan dalam jamaah semakin terasa dan kekritisan dalam jamaah semakin menjauh. Mereka tidak diperbolehkan tumbuh menjadi jamaah yang kritis karena kekritisan akan mengancam keberlangsungan sistem organisasi.

\section{Perlawanan Ideologi Moderatisme Melawan Hegemoni Radikal}

Radikalisme belakangan ini menjadi gejala umum di dunia Islam, termasuk di Indonesia. Gejala radikalisme di dunia Islam bukan fenomena yang datang tiba-tiba. Ia lahir dalam situasi politik, ekonomi, dan sosial-budaya. Islam radikal, terus mencoba melawan. Perlawanan itu muncul dalam bentuk melawan kembali kelompok yang mengancam keberadaan mereka. Mereka berjuang untuk menegakkan cita-cita yang mereka yakini. Mereka berjuang dengan kerangka nilai atau identitas tertentu yang diambil dari warisan masa lalu maupun konstruksi baru.

Kini, gerakan radikal Islam telah terfragmentasi dalam beragam organisasi. Namun, ada sejumlah benang merah yang bisa ditarik dari berbagai kelompok Islam radikal, yaitu keyakinan yang sangat kuat bahwa Islam adalah satu-satunya solusi untuk menyelesaikan berbagai krisis di negeri ini, perjuangan yang tidak kenal lelah menegakkan syariat Islam, resistensi terhadap kelompok yang berbeda pemahaman dan keyakinan, serta penolakan dan kebencian terhadap segala sesuatu yang berbau Barat.

Indonesia sebagai salah satu negara muslim terbanyak tidak luput dari radikalisme. Radikalisme yang di lakukan oleh sekelompok orang atau organisasi yang terjadi di Indonesia pada intinya adalah sebuah gerakan politik yang bercita-cita menjadikan Islam sebagai sebuah ideologi. Mereka ingin mewujudkan Indonesia sebagai Negara Daulah Islamiyah Indonesia. Mereka ingin menggunakan syariat Islam sebagai dasar hukumnya. Kelompok Islam radikal selalu berpandangan jika hanya syariat Islam yang merupakan suatu kebenaran dalam menjalankan hukum negara dan segala sesuatu yang menyangkut kehidupan manusia dan mereka menginginkan itu terwujud di Indonesia.

Mereka selalu mengkafirkan orang dan kelompok yang berbeda pandangan dengan mereka. Islam radikal berpandangan jika hanya ajaran mereka yang paling benar. Seseorang yang belum berhijrah berarti termasuk orang kafir dan bukan bagian dari golongan mereka. Dalam penelitian novel Tuhan, Izinkan Aku Menjadi Pelacur! dihasilkan beberapa poin mengenai ciri-ciri gerakan yang terindikasi sebagai gerakan Islam radikal. Salah satunya 
adalah 1) menganggap pemerintahan Indonesia sebagai pemerintah yang thaghut, 2) mereka yang memiliki paham radikal memiliki ikatan batin yang lebih besar dengan kelompok dibandingakan dengan keluarga, 3) pengkaderisasian yang dilakukan secara tertutup, 4) membayar uang infaq sebagai uang perjuangan, 5) berelana cingkrang dan berjenggot bagi lelaki, berjilbab besar atau bercadar bagi perempuan, 6) umat Islam di luar kelompoknya dianggap kafir sebelum berhijrah.

Selain radikal penulis juga menemukan ideologi moderatisme dalam penelitian novel TIAMP, seperti nilai-nilai Ahlussunah Wal Jamaah (aswaja) di dalamnya, antara lain; tawassut (moderat), tawazun (berimbang), tasamuh (toleransi), dan i'tidal (adil). Sikap ini yang menjadi idiologi bangkit yang diperjuangkan oleh pengarang.

Ideologi moderatisme ini yang kemudian dihadirkan pengarang sebagai ideologi kebangkitan yang akhirnya digunakan Kiran untuk melawan hegemoni radikalisme dalam novel TIAMP. Ia ingin menegakkan keadilan yang tidak ia dapatkan saat bergabung dengan Jamah Daulah Islamiyah. Ketidakadilan tersebut tergambar lewat kepemimpinan komandan Sardi yang selalu semena-mena. Komandan Sardi tidak memberikan pengayoman sebagaimana pemimpin yang baik, ia justru menutupi segala informasi mengenai pergerakan jamaah. Sikap kritis tidak diperbolehkan hidup dalam jamaah karena hal itu akan membahayakan pergerakan jaringan.

Kemudian keanehan yang penulis temukan adalah ketidaksesuaian ajaran Jamaah Daulah Islamiyah dengan ajaran Islam, yaitu adalah boleh menyetorkan uang infaq perjuangan dengan berbagai cara. Termasuk menipu, berbohong, mencuri, melacur dan berbagai cara lain yang tidak diridhoi oleh Allah. Penjelasan ini terdapat dalam kutipan TIAMP sebagai berikut.

"Kita boleh berbohong, sepanjang itu berkaitan dengan kepentingan Islam dan kerahasiaan perjuangan. Bahkan, boleh menipu, mencuri, merampok, menjual barang-barang pribadi, maupun melacur. Ini jihad dan bukan untuk foya-foya. Dan Allah Maha Tahu itu semua," begitu aku ingat seorang ustad di Jemaahku sesaat setelah aku dilantik. Walau aku sangat begidik waktu itu, toh kuterima dengan pasrah. Sebab anggapanku ini perjuangan mulia (TIAMP:60-61).

Dalam kutipan tersebut tergambar bagaimana mereka mengajarkan sesuatu tindakan yang sebenarnya termasuk dalam dosa. Padahal dalam Islam memiliki ketetapan, jika sarana memiliki hukum yang sama dengan tujuan, maksudnya adalah jika sarananya baik, maka tujuannya pun baik. Apabila tujuannya haram, maka sarananya juga haram. 


\section{SIMPULAN}

Dalam novel Tuhan, Izinkan Aku Menjadi Pelacur! Muhidin menghadirkan dua perlawanan ideologi, yaitu ideologi radikalisme yang merupakan ideologi dominan dan ideologi moderatisme yang merupakan ideologi yang diperjuangkan Kiran sebagai tokoh utama dalam novel TIAMP. Tujuannya adalah agar para pembaca tidak terjerumus dalam sebuah ideologi yang salah, sehingga mereka bisa memaknai mana yang benar, mana yang tidak.

Dalam penelitian novel Tuhan, Izinkan Aku Menjadi Pelacur! dihasilkan beberapa poin mengenai ciri-ciri gerakan yang terindikasi merupakan gerakan Islam radikal. Diantaranya adalah 1) menganggap pemerintahan Indonesia sebagai pemerintah yang thaghut, 2) mereka yang memiliki paham radikal memiliki ikatan batin yang lebih besar dengan kelompok dibandingkan dengan keluarga, 3) pengkaderisasian yang dilakukan secara tertutup, 4) membayar uang infaq sebagai uang perjuangan, 5) bercelana cingkrang dan berjenggot bagi lelaki, berjilbab besar atau bercadar bagi perempuan, 6) menganggap umat Islam di luar kelompoknya merupakan orang kafir sebelum berhijrah.

Penulis juga menemukan adanya ideologi moderatisme sebagai ideologi bangkit yang ditawarkan pengarang dalam novel TIAMP yang merupakan penggambaran dari nilai-nilai Ahlussunah Wal Jamaah (aswaja) di dalamnya antara lain; tawassut (moderat), tawazun (berimbang), tasamuh (toleransi), i'tidal (adil) untuk melawan idelogi organisasi Jamaah Daulah Islamiyah.

\section{Daftar Pustaka}

Bellamy, Richard. 1987. Modern Italian Social Theory, From Pareto to the Present. Terj. Vedi R. Hadiz,Teori Sosial Modern; Perspektif Italia, 1990. Jakarta: LP3S.

Bellamy, Richard. 1990. Teori Sosial Modern, Perspektif Itali. Jakarta: LP3ES.

Damono, Sapardi Djoko. 1984. Sosiologi Sastra Sebuah Pengantar Singkat. Jakarta: Pusat Bahasa Departemen Pendidikan Nasional.

Departemen Agama RI. 1976. Al-Quran dan Terjemahannya. Jakarta: Bumi Restu.

Dahlan, Muhidin M. 2010. Tuhan, Izinkan Aku Menjadi Pelacur!. Yogyakarta: Scriptamament.

Dhofier, Zamakhsyari. 1983. Tradisi Pesantren Studi tentang Pandangan Hidup Kyai. Jakarta: LP3S. 
Rr. Via Rahmawati, Perlawanan Ideologi Moderatisme Melawan Hegemoni Radikalisme Dalam Novel Tuhan, Izinkan Aku Menjadi Pelacur! Karya Muhidin M. Dahlan

Escarpit, Robert. 2005. Sosiologi Sastra. Jakarta: Yayasan Obor Indonesia.

Gramsci, Antonio. 1971. Selections from Prison Notebook, Quentin Hoare and Smith (ed), New York: International Publisher.

Hasan dan Koentjaraningrat. 1997. Metode-metode Penelitian Masyarakat. PT. Gramedia Pustaka Utama: Jakarta.

Hendarto, Heru. 1973. "Mengenal Konsep Hegemoni Gramsci: dalam Diskursus Kemasyarakatan dan Kemanusiaan" dalam Tim Redaksi Driyakarya. Jakarta: Gramedia.

Patria, Nezar dan Andi Arief. 2003. Antonio Gramsci Negara \& Hegemoni. (cetakan ke-2). Yogyakarta: Pustaka Pelajar. 